\title{
Cationic vesicles for efficient shRNA transfection in the MCF-7 breast cancer cell line
}

This article was published in the following Dove Press journal:

International Journal of Nanomedicine

\author{
Pardis Mokhtary ${ }^{1,2}$ \\ Bita Javan ${ }^{1,3}$ \\ Mahrokh Sharbatkhari ${ }^{4}$ \\ Alireza Soltani ${ }^{5}$ \\ Vahid Erfani-Moghadam ${ }^{1,2}$ \\ 'Medical Cellular and Molecular \\ Research Center, Golestan \\ University of Medical Sciences, \\ Gorgan, Iran; ${ }^{2}$ Department of \\ Medical Biotechnology, School of \\ Advanced Technologies in Medicine, \\ Golestan University of Medical \\ Sciences, Gorgan, Iran; ${ }^{3}$ Department \\ of Molecular Medicine, School of \\ Advanced Technologies in Medicine, \\ Golestan University of Medical \\ Sciences, Gorgan, Iran; ${ }^{4}$ R\&D Section, \\ Arya Tina Gene Biopharmaceutical \\ Company, Gorgan, Iran; ${ }^{5}$ Golestan \\ Rheumatology Research Center, \\ Golestan University of Medical \\ Sciences, Gorgan, Iran
}

Correspondence: Vahid Erfani-Moghadam Medical Cellular and Molecular Research Center, Golestan University of Medical Sciences, Shast Kolah Street, PO Box: 4934I746II, Gorgan, Iran Tel +98 I7 32450995

Email vahid.erfani@goums.ac.ir
Introduction: Novel and safe delivery solutions for RNAi therapeutics are essential to obtain the full potential of cancer gene therapy.

Methods: In this study, cationic vesicular nanocarrier was applied for delivering lnc urothelial carcinoma-associated 1 (lnc UCA1) shRNA expression vector to MCF-7 cells. The physicochemical characteristics, cytotoxicity, and transfection efficiency of cationic vesicles prepared from various molar ratios of amphiphilic surfactant Tween $80(\mathrm{~T})$, squalene (S), cationic charge lipid didodecyldimethylammonium bromide, and polyethylenimine were investigated. The particle sizes of the vesicles in the nanosize range were determined by dynamic light scattering and transmission electron microscopy.

Results: Gel protection assay with agarose gel electrophoresis showed cationic vesicles can protect the shRNA plasmid from DNase 1 enzyme. 3-(4,5-Dimethylthiazol-2-yl)-5-(3carboxymethoxyphenyl)-2-(4-sulfophenyl)-2H tetrazolium, inner salt result showed no significant cytotoxicity was caused in MCF-7 cancer cell line by (T:S):polyethylenimine cationic vesicles. 3-(4,5-Dimethylthiazol-2-yl)-5-(3-carboxymethoxyphenyl)-2-(4-sulfophenyl)-2H tetrazolium, inner salt assay, fluorescence microscope images, and flow cytometry analyses confirmed that $(\mathrm{T}: \mathrm{S})_{1,040 \mu \mathrm{M}}$ with $4.3 \mu \mathrm{g} / \mathrm{mL}$ of PEI vesicles provided effective transfection without significant cytotoxicity. Furthermore, we found efficient UCA1 shRNA transfection and significant $(P<0.05)$ cell cycle arrest and apoptosis in MCF-7 cancer cells.

Conclusion: The novel nonviral vesicular nanocarrier, (T:S) $)_{1,040} \mu \mathrm{M}$ with $4.3 \mu \mathrm{g} / \mathrm{mL}$ of PEI, might be safe and efficient for cancer gene therapy and can be used in further in vitro and in vivo studies.

Keywords: cationic vesicles, shRNA, UCA1, apoptosis, gene delivery

\section{Introduction}

Recent nanotechnology advances empower drug delivery in medical sciences. Nonviral vectors are appropriate candidates for efficient and safe gene delivery. Vesicles which comprise nonionic surfactants and excipients, known as niosomes, are safe and not imunugene. ${ }^{1}$ Some excipients similar to cholesterol or squalene can be applied for stabilizing the vesicular structure and others such as cationic lipids or polymers can be used to achieve appropriate properties for the nucleic acid transfection. ${ }^{2-4}$ Niosomes potentially ameliorate drug delivery and bioavailability and show enhancement effects on factors such as stability, solubility, entry and controlled release of the drugs, simultaneously, decreasing immunogenicity. ${ }^{5,6}$ As a preliminary study of ocular gene therapy, Puras et $\mathrm{al}^{7}$ developed a cationic niosome containing a plasmid that efficiently transfected into the retina of rats without significant angiogenesis.

Gene therapy researchers have provided enormous hope to treat a wide variety of cancers, infections, respiratory, and nervous diseases..$^{8-11}$ Overcoming the systemic submit your manuscript Dovepress $f y$ in 0

http://dx.doi.org/10.2147/IJN.SI77674 
delivery of RNAi is a hard challenge to produce gene drugs. RNAi by shRNA can be stable even for 2 years in comparison with siRNA that degrades $99 \%$ in 2 days. ${ }^{12,13}$ The synthesis cost, fast systemic clearance, weak cell entrance, and lack of specificity for tissue targeting are considered the main barriers for potential clinical applications of siRNA. Here we present shRNA with survivin promoter to achieve cancer cell targeting. Several tumor-specific promoters such as survivin were evaluated for targeted cancer gene therapy. ${ }^{14}$ Survivin is an antiapoptotic gene overexpressed in a wide range of human cancers with a low or no expression in normal tissues.

Recently, genes in regulatory noncoding RNAs have been considered for gene therapy studies. ${ }^{10}$ Urothelial carcinomaassociated 1 (UCA1) long noncoding RNA was discovered for the first time in bladder cancer. ${ }^{15}$ This long noncoding RNA forms a complex with heterologous nuclear ribonucleoprotein; its expression is mainly restricted in the nucleus and it is also involved in pre-mRNA processing. ${ }^{16}$ Although there is little information about the molecular mechanisms underlying UCA1 biological activity, especially its antiapoptotic effects, UCA1 has known effects on cell proliferation, motility, invasion of tumors, and drug resistance in different cancers. $^{17-19}$

Cationic lipids are efficient excipients for plasmid transfection. Plasmid transfection improvement has been reported in the lung of $\mathrm{BALB} / \mathrm{c} \mathrm{mice}^{20}$ and in rat retina, in an animal model survey. ${ }^{7}$ In another study, a cationic niosome formed efficient complexes for codelivery of an anticancer phytochemical and a resistance-related gene siRNA in MCF-7 breast cancer cells and nude mice. ${ }^{21}$ Opanasopit et al reported high transfection efficiency and low cytotoxicity of cationic niosomes prepared in vitro by span 20 , cholesterol, and novel spermine-based lipids as cationic counterparts. ${ }^{22}$ More recently, Tagalakis et al developed a bioengineered nanovesicle platform by synthesis and nanoformulation of cationic peptides, which provide the appropriate positive zeta potentials and targeting simultaneously. These giant unilamellar vesicles make stable nanosize complexes with safe and efficient nucleic acid transfection in vitro and in vivo. ${ }^{23}$

The adenoviruses-based gene delivery systems are more efficient for plasmid delivery relative to branched polyethylenimine (PEI)-based polyplexes, ${ }^{24,25}$ but PEI-based nanoformulations for modification in binding, uptake, endosomal escape, and cell nuclear entrance could enhance gene delivery efficiency close to that of adenoviruses for future potential application of nonviral drug delivery systems.

In this study, we describe the application of several cationic vesicle formulations comprising a cationic lipid (didodecyldimethylammonium bromide [DDAB]), a cationic polymer (PEI), squalene, and Tween 80 (polysorbate 80 ), with the ability of transfection of a large plasmid $(6.5 \mathrm{~kb})$ containing the UCA1 shRNA. Additionally, we explore the antiapoptotic role of UCA1 in the MCF-7 breast cancer cell line. There are few studies focusing on the antiapoptotic effect of UCA1 in human breast cancer. Here, the UCA1 lncRNA shRNA expression vector with survivin promoter was constructed and delivered by vesicular nanocarriers to MCF-7 cells.

\section{Materials and methods Materials}

DDAB, squalene, Tween 80, and PEI with an average molecular weight of 25,000 (PEI-25k) were purchased from Sigma-Aldrich Co. (St Louis, MO, USA). Culture medium (RPMI-1640) and FBS were purchased from Thermo Fisher Scientific (Waltham, MA, USA). Dulbecco's PBS was purchased from Thermo Fisher Scientific. Ultrapure water was obtained from EMD Millipore RIOs ${ }^{\mathrm{TM}}$. Annexin V Apoptosis Detection kit was purchased from BioLegend (Shanghai, China). MCF-7 (human breast adenocarcinoma cell line) was obtained from Pasteur Institute (Tehran, Iran). 3-(4,5Dimethylthiazol-2-yl)-5-(3-carboxymethoxyphenyl)-2-(4sulfophenyl)-2H tetrazolium, inner salt (MTS) was purchased from Promega Corporation (Fitchburg, WI, USA). Reverse transcription-PCR (RT-PCR) Master Mix Reagents kit and cDNA Synthesis kit were purchased from Fermentas. Other chemicals were of reagent grade and used without further purification.

\section{Construction of UCAI shRNA expression vector}

Using bioinformatics tools, the core promoter sequence of survivin (Sur-p; 269 bp) was selected and cytomegalovirus (CMV) enhancer was placed upstream the survivin core promoter to improve promoter activity. Thereafter, sequence alignment was performed in CLUSTAL omega to find conserved sequences between $U C A 1$ gene variants and a specific shRNA was designed via InvivoGen-siRNA Wizard software and placed downstream of enhancer/promoter. Finally, the 772 bp nucleotide fragment was synthesized by Shine Gene Molecular Biotech Company and subsequently cloned in the pRNAT-U6.1/Neo expression vector (6,380 bp; GenScript Corp., Piscataway, NJ, USA) to construct the pRNATCMVenhancer-Sur-p-sh (UCA-1) vector. Double digestion analysis was used to verify substitution of the U6 promoter into the CMVenhancer-Sur-p. Plasmid DNA was extracted from Escherichia coli transformants using Fastfilter Endo-free Plasmid Midi kit (Omega Bio-Tek Inc., Doraville, GA, USA). 


\section{Preparation of the complexes}

Briefly, DDAB cationic lipid was dispersed in PBS solution containing Tween 80 emulsifier and squalene. First, Tween 80 and squalene were dissolved in chloroform and this emulsion was then shaken for 4 hours at $37^{\circ} \mathrm{C}$ for thin film formation. Then, PBS containing DDAB and PEI was added to the thin film and then the emulsion was vortexed for 30 seconds and incubated for 40 minutes at $37^{\circ} \mathrm{C}$ until it became clear and transparent. To get different molar and charge ratios, lipoplexes were incubated for 30 minutes at room temperature before use to enhance electrostatic interactions.

\section{Binding, DNase I protection, and SDS-induced release of DNA}

Vectors in a concentration of $0.03 \mu \mathrm{g}$ DNA $/ \mu \mathrm{L}$ were subjected to electrophoresis on an ethidium bromide-containing gel (1\% agarose). Subsequently, bands were photographed with a Vilber (Vilber Lourmat, Marne-la-Vallée, France) E-BOX. In the protection study, $1 \mathrm{U}$ of DNase and $1.2 \mu \mathrm{g}$ DNA (Sigma-Aldrich) were incubated $\left(37^{\circ} \mathrm{C}\right)$ with the vectors and complexes for 30 minutes. Then, a $2 \%$ sodium dodecyl sulfate (SDS) solution was added as a DNA release reagent. Samples were subjected to agarose gel electrophoresis and compared to untreated DNA.

\section{Physical properties of particles: size, morphology and zeta potential}

Dynamic light scattering (DLS) assay was performed to determine the physical properties of the cationic vesicles. The zeta potential, size, and polydispersity index (PDI) of the vesicles in PBS (pH 7.4) were analyzed by DLS (Zetasizer Nano ZS; Malvern Instruments, Malvern, UK) using an argon laser beam at $633 \mathrm{~nm}$ and a $90^{\circ}$ scattering angle.

\section{Transmission electron microscopy (TEM) and ultraviolet (UV)-visible spectroscopy} TEM (EM10C; Carl Zeiss Meditec AG, Jena, Germany) was used to observe the morphology, size, and polydispersity of complexes. Complexes were sonicated for 10 minutes in a bath ultrasonicator. Thereafter, a small drop of the sample solution was deposited on to a copper grid covered by $0.2 \%$ polyvinyl formal (Vinylec K). The grid was allowed to dry at room temperature. Prior to observation, complexes were negatively stained with a solution of $2 \%$ uranyl acetate. The UV-visible spectra were obtained using a Cary 60 UV-visible Spectrophotometer (Agilent Technologies, Santa Clara, CA, USA) in an absorbance range between 200 and $700 \mathrm{~nm}$.

\section{Human monocyte isolation}

Informed consent letters were obtained from the blood donors, and the toxicity evaluation study in peripheral blood mononuclear cells (PBMCs) was approved by Golestan University of Medical Sciences Ethics Committee. Peripheral venous blood samples $(10 \mathrm{~mL})$ were taken by venipuncture from two students, and isolation of PBMCs with Lymphodex (Inno-Train 002041600) was performed according to the manufacturer's protocol. Briefly, $10 \mathrm{~mL}$ of peripheral blood was mixed with $1 \mathrm{~mL}$ sodium citrate. The mixture of blood and PBS (1:4, v:v) was mildly shaken and the tubes were centrifuged for 3 minutes at $1,000 \times g$ at room temperature. The white pellet obtained was cautiously transferred to $4 \mathrm{~mL}$ of cooled Lymphodex. Then, again, the tubes were centrifuged for 30 minutes at $1,000 \times g$ at room temperature. Aspiration of white rings of lymphocytes was done cautiously with a Pasteur pipette and washing with PBS solution was performed. Then, the pellet was washed three times and centrifuged at $250 \times \mathrm{g}, 175 \times \mathrm{g}$, and $150 \times \mathrm{g}$ for 10 minutes. After the last centrifugation, PBMCs were cultivated in six-well plates in a humidified atmosphere at $37^{\circ} \mathrm{C}, 5 \% \mathrm{CO}_{2}$ for $1-3$ hours. The supernatant medium (which contained nonadherent cells) was then removed and the adherent cell layer was washed twice with warm PBS and replaced by fresh DMEM (Thermo Fisher Scientific) with $10 \%$ FBS (Thermo Fisher Scientific). The following day, the cells were detached by adding ice-cold $0.02 \%$ EDTA/PBS solution for 10 minutes and then firmly tapping the flask to obtain mononuclear cells.

\section{Cell culture}

Human breast MCF-7 and MDA-MB-231 cancer cell lines were obtained from the Pasteur Institute. MCF-7, MDA-MB-231, and extracted mononuclear cells were cultured in RPMI 1640 medium (Thermo Fisher Scientific) supplemented with 10\% FBS and penicillin-streptomycin solution at $37^{\circ} \mathrm{C}$ in a humidified atmosphere of $5 \% \mathrm{CO}_{2}$. After third passage, the cells were split and used for further experiments.

\section{Cell toxicity assay}

MCF-7 and MDA-MB-231 cells were seeded at $1 \times 10^{4}$ cells per well in a 96-well plate in a final volume of $200 \mu \mathrm{L} /$ well at $\sim 24$ hours before the assay. Cells were exposed to different complexes at various concentrations. At the end of the incubation time (72 hours), $20 \mu \mathrm{L} /$ well MTS reagent (Promega Corporation) was added to each sample and the plates were incubated for 2.5 hours at $37^{\circ} \mathrm{C}$ in standard culture conditions. Finally, the absorbances were measured at $490 \mathrm{~nm}$ 
using ELISA reader (Awareness Technology ChroMate ${ }^{\circledR}$ Microplate Reader). The estimated percentage of cell viability was compared with the value of the untreated control cells.

\section{Cell transfection}

The knockdown of lnc-UCA1 was performed by synthetic shRNA. A day before transfection, cells were seeded in six-well plates at a density of $3 \times 10^{5}$ cells per well in $2.0 \mathrm{~mL}$ RPMI 1640 growth medium with 10\% FBS. Prior to transfection, cationic vesicular complexes were prepared as described above and added to the wells to a final volume of $2 \mathrm{~mL}$ with serum-free transfection medium. Then, after 5 hours of incubation, the transfection mixture was replaced with fresh medium containing serum and cells were maintained under normal growth conditions. Finally, after 72 hours of transfection, the cells were harvested in Trizol (Tri Reagent; Sigma-Aldrich) for RNA isolation.

\section{RNA extraction and quantitative RT-PCR analysis}

The treated and untreated cells were washed with PBS and harvested following 72 hours of incubation. Total RNA was extracted from the cells using Trizol reagent according to the manufacturer's instruction. RNAs were reverse transcribed using the PrimeScript RT reagent kit (Thermo Fisher Scientific). The quantitative PCR experiments were used for the analysis of UCA1 gene expression using a standard SYBR Green PCR kit (Thermo Fisher Scientific) protocol. PCR reactions were run in triplicate for three independent experiments. The sequences of the primers (Metabion) are as follows: UCA1F, 5' ACGCTAACTGGCACCTTGTT 3', UCA1R, 5' TGGGGATTACTGGGGTAGGG 3', and 18SF and $18 \mathrm{SR}$ as internal control were $5^{\prime}$ GATACCCGTTG AACCCCATT 3' and 5' CCATCCAATCGGTAGTAGCG 3', respectively.

\section{Cell cycle analysis}

Cells were harvested 72 hours after transfection, washed with ice-cold PBS, and fixed with 75\% ethanol for 2 hours at $4^{\circ} \mathrm{C}$. Cells were washed and suspended in PBS containing $100 \mu \mathrm{g} / \mathrm{mL}$ RNase A (Thermo Fisher Scientific) and then incubated at $37^{\circ} \mathrm{C}$ for 30 minutes to eliminate the intracellular RNA. Finally, cells were stained with propidium iodide (PI; $10 \mu \mathrm{g} / \mathrm{mL}$; Sigma-Aldrich) in dark for 15 minutes. The results were assessed by flow cytometer (BD Biosciences, San Jose, CA, USA). The percentages of the cells in G0/G1, $\mathrm{S}$, and $\mathrm{G} 2 / \mathrm{M}$ phases were determined and compared with the control group. Each experiment was performed in triplicate.

\section{Apoptosis detection}

The apoptotic index of each sample was measured through flow cytometry assays using FITC Annexin V and PI staining kits (BioLegend ${ }^{\circledR}$, San Diego, CA, USA) according to the manufacturer's instructions. MCF-7 cells were seeded $\left(0.5 \times 10^{6}\right.$ cells/well $)$ into six-well plates and allowed to adhere overnight before treatments. After 72 hours trypsindigested cells were centrifuged at 1,100 rpm for 5 minutes. Cells were washed twice with cold BioLegend's cell staining buffer and then resuspended in Annexin $\mathrm{V}$ binding buffer at a concentration of $5 \times 10^{5}$ cells $/ \mathrm{mL}$. One hundred microliters of the cell suspension was transferred to a $5 \mathrm{~mL}$ test tube. Five microliters of fluorescein isothiocyanate Annexin V and $10 \mu \mathrm{L}$ of PI solution were added. After gentle vortexing, the cells were incubated for 15 minutes at room temperature $\left(25^{\circ} \mathrm{C}\right)$ in the dark. Four hundred microliters of Annexin $\mathrm{V}$ binding buffer was added to each tube and immediately analyzed using BD accurate $\mathrm{C} 6$ flow cytometer. The data were evaluated using a BD Accuri ${ }^{\mathrm{TM}} \mathrm{C} 6$ software (BD Biosciences).

\section{Evaluation of gene delivery efficiency in vivo}

The efficiency of gene delivery of cationic vesicles into the tumor cells was evaluated by pRNAT-U6.1/Neo expression vector that consists of a green fluorescent protein gene under the control of CMV promoter. After 1-week acclimatization of female BALB/c mice ( 8 weeks old; weighing $20 \mathrm{~g}$ ), subcutaneous tumors were established by injecting 4T1 $\left(4 \times 10^{6}\right.$ cells in $100 \mu \mathrm{L}$ PBS) into the upward side of the right hind leg of mice. When the tumor size reached $100 \mathrm{~mm}^{3}$ in volume, the complex of plasmid with cationic vesicles was injected intratumorally.

\section{Immunohistochemistry of GFP}

Cryoprotection method was used for the preparation of the tissue sections. Vector-treated tumor was resected from mice and placed in cold PBS to wash out the blood. Then the tumor was cut into appropriate sizes and frozen. The frozen tissues were cut into thin sections by a cryostat at $-20^{\circ} \mathrm{C}$ and transferred onto slides. After fixation, the tissue sections were incubated in DAPI solution for 10 minutes to dye the nuclei. Finally, the slides were observed by fluorescence microscopy.

\section{Statistical analysis}

Statistical analysis was performed using SPSS 19.0 software. Results were expressed as mean \pm SD. Statistical significance 
among groups was determined by one-way ANOVA and Student's $t$-test. $P$-values $<0.05$ were considered statistically significant.

\section{Results and discussion UCAI shRNA expression vector with survivin promoter}

Multiple sequence alignment of UCA1 gene variants with CLUSTAL omega was done and the shRNA sequence of 5'-ggtaATGTATCATCGGCTTAGttcaagagaCTAAGCCGA TGATACATTACCtaaaataaa-3' was designed for one conserved region of UCA1 gene sequences. The final sequence (772 bp) was cloned into the BglII and HindIII restriction sites of the pRNAT-U6.1/Neo expression vector and verified by double digestion and DNA sequencing.

\section{DNase I protection of plasmid DNA by vesicular formulations}

Technically, agarose gel DNase I protection assay shows the efficient ratios of cationic nanocarrier/plasmid formulations which can protect DNA from degradation. Figure 1 shows that free plasmid DNA was degraded completely when exposed to the DNase I (Lane L). The presence of plasmid bands shows that all the vesicles containing PEI protected the DNA against enzymatic digestion. Incubation with DNase I for 30 minutes at $37^{\circ} \mathrm{C}$ degraded plasmid DNA in the vesicles which contained only squalene and Tween 80 (520 and 1,040 $\mu \mathrm{M}$; Lanes E and F, respectively). Additionally, vesicles containing DDAB 42, 62.5, and $84 \mu \mathrm{M}$ could not protect DNA properly. Therefore, all treatments containing PEI were selected for further experiments in this study.

\section{Physical properties of vesicles: size, morphology, and zeta potential and UV-visible spectra}

Evaluation of size, zeta potential, and morphology of the nanocarriers was performed by DLS (Table 1) and TEM (Figure 2). Generally, the DLS and TEM results showed that the cationic vesicles comprising Tween 80, squalene, DDAB, and PEI had two particle forms, micelle like and niosome (polymersome like). Preferably, if there is more than one population of nanoparticles, then determination of hydrodynamic diameter should be considered based on volume (\% vs mean size) parameter of DLS, as represented in Table 1. These data are similar to our previous result obtained with monomethoxy poly [ethylene glycol]-oleate vesicles, which showed that lowering the concentration of the blocks leads to increase in vesicle size from micellar $(10-30 \mathrm{~nm})$ to polymersomes (usually larger than $100 \mathrm{~nm}),{ }^{26}$ and at higher concentration of blocks, the micellar form is dominant in which the formation of micelles besides larger vesicles such as niosomes or polymersomes (comprising lipid-size surfactants) has been widely reported. ${ }^{27}$ It seems that thermodynamically, there is a tendency to form two populations of micelles and larger vesicles. Another explanation of formation of small micellar size particles is that the potential molecular condensation of plasmid DNA with cationic counterpart may yield small-sized complexes which are close to viruses and micelles. Similar to our result, Perales et al obtained small transfecting particles, 10-12 nm in diameter, with poly(L-lysine) and described successful in vivo gene transfer by tuning the parameters of the polyplex formation, such as the ionic strength of the solvent. ${ }^{28}$

Interestingly, the DLS data showed that using a higher concentration of DDAB increased the PDI of the cationic

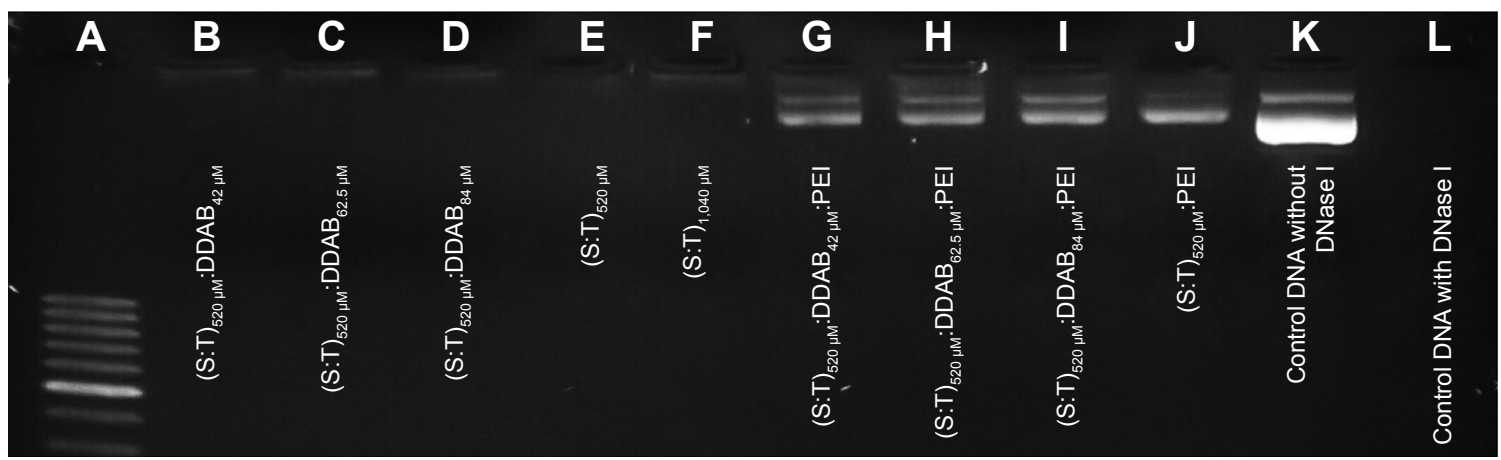

Figure I DNA protection assay. All lanes (except K) represent DNase I-treated contents.

Notes: (A) 50 bp DNA ladder. (B-D) Vesicles containing squalene, Tween 80, and DDAB. (E-F) Vesicles containing only squalene and Tween 80 . (G-I) Vesicles containing squalene, Tween 80, DDAB, and PEl. (J) Vesicles containing squalene, Tween 80, and PEI. (K) Control (free DNA without DNase I). (L) Control (free DNA with DNase I). Abbreviations: DDAB, didodecyldimethylammonium bromide; PEl, polyethyleneimine; S, squalene; T, Tween 80. 
Table I Size distribution and zeta potential of cationic vesicles

\begin{tabular}{|l|l|l|l|l|}
\hline \multirow{2}{*}{ Treatments } & \multicolumn{2}{|l|}{ Particle size (nm) } & PDI & $\begin{array}{l}\text { Zeta } \\
\text { potential (mV) }\end{array}$ \\
\cline { 2 - 5 } & Micelles & $\begin{array}{l}\text { Niosome } \\
\text { (polymersomes) }\end{array}$ & & -4.85 \\
\hline$(\mathrm{T}: \mathrm{S})_{520 \mu \mathrm{m}}$ & $12.71 \pm 3.082(99.6 \%)$ & $107.5 \pm 30.37(0.4 \%)$ & 0.146 & +7.75 \\
\hline$(\mathrm{T}: \mathrm{S})_{520 \mu \mathrm{m}}: \mathrm{DDAB}_{42 \mu \mathrm{M}}: \mathrm{PEI}$ & $15.59 \pm 3.975(99.8 \%)$ & $289.7 \pm 90.07(0.2 \%)$ & 0.244 & +7.47 \\
\hline$(\mathrm{T}: \mathrm{S})_{520 \mu \mathrm{m}}: \mathrm{DDAB}_{84 \mu \mathrm{M}}: \mathrm{PEI}$ & $13.88 \pm 3.448(99.5 \%)$ & $179.1 \pm 67.76(0.5 \%)$ & 0.677 & +6.16 \\
\hline$(\mathrm{T}: \mathrm{S})_{520 \mu \mathrm{m}}: \mathrm{PEI}$ & $12.79 \pm 3.631(99.7 \%)$ & $333 \pm 107.1(0.3 \%)$ & 0.330 & \\
\hline
\end{tabular}

Notes: Size is measured as hydrodynamic diameter. All data are shown as volume \% vs mean size \pm SD.

Abbreviations: DDAB, didodecyldimethylammonium bromide; PEI, polyethyleneimine; PDI, polydispersity index; S, squalene; T, Tween 80.

vesicles (PDI of 0.677 for $84 \mu \mathrm{M}$ compared with 0.244 for $42 \mu \mathrm{M}$ DDAB), as found in Table 1 . This result is in accordance with that of Zabner et al which demonstrated that the population of lipid-DNA complexes has a wide range polydispersity. ${ }^{29}$

The positive zeta potential of the complexes comprising plasmid DNA and the cationic vesicles (ranged from +3.26 to $+7.75 \mathrm{mV}$; Table 1) was induced by DDAB and PEI in the structure. It seems that their positive charges are adequate for the vesicular stability (no precipitation observed by naked eye after 30 days). In addition, this slightly positive net charge potentially can promote interaction with the negatively charged cell surface and the cell entrance.

The UV-visible spectra were recorded using a spectrophotometer (Cary 60 UV-visible) in an absorbance range between 200 and $700 \mathrm{~nm}$ (Figure 3). When we examined the UV-visible spectra of $(\mathrm{T}: \mathrm{S})_{520 \mu \mathrm{M}}: \mathrm{D}_{84 \mu \mathrm{M}}$ and $(\mathrm{T}: \mathrm{S})_{1,040 \mu \mathrm{M}}$ in PBS buffer ( $\mathrm{pH}=7.4)$, an obvious blue shift of the maximum absorption was observed. The absorption wavelength increased from $230 \mathrm{~nm}$ for $(\mathrm{T}: \mathrm{S})_{1,040 \mu \mathrm{M}}$ to $260 \mathrm{~nm}$ for $(\mathrm{T}: \mathrm{S})_{1,040 \mu \mathrm{M}}$ :

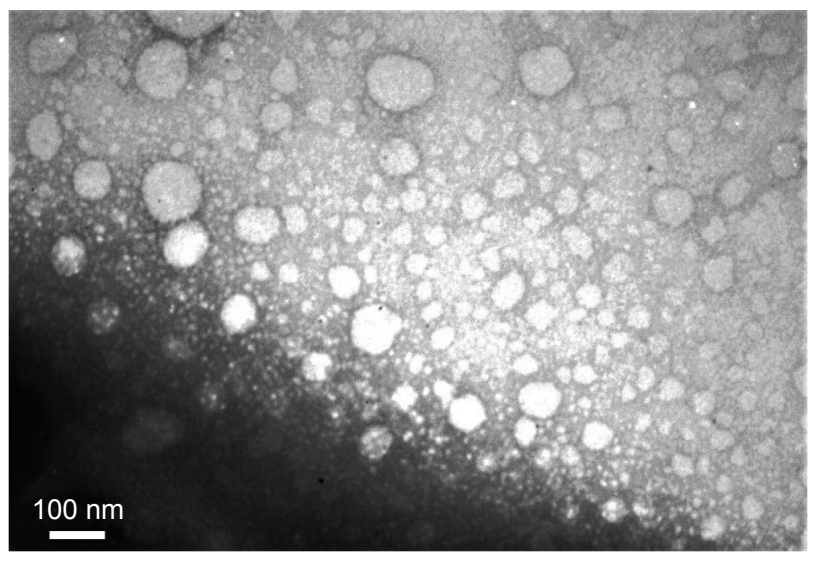

Figure 2 TEM image of the polyplex of the plasmid with $(\mathrm{T}: \mathrm{S})_{520 \mu \mathrm{M}}: \mathrm{PEI}$ formulation. Notes: The cationic vesicles comprise $(520 \mu \mathrm{M}$ of each of them) and polyethylenimine $(4.3 \mu \mathrm{g} / \mathrm{mL})$. There are two particle forms, micelle like (smaller vesicles) and niosome or polymersome like (larger vesicles). Scale bar is $100 \mathrm{~nm}$.

Abbreviations: PEl, polyethyleneimine; S, squalene; T, Tween 80; TEM, transmission electron microscopy. polyethylenimine (PEI; P means with plasmid), whereas the absorption spectra in $(\mathrm{T}: \mathrm{S})_{520 \mu \mathrm{M}}: \mathrm{D}_{84 \mu \mathrm{M}}$ were not significantly changed and increased from 280 to $285 \mathrm{~nm}$ in $(\mathrm{T}: \mathrm{S})_{520 \mu \mathrm{M}}: \mathrm{D}_{84 \mu \mathrm{M}}:$ PEI. No change in the absorption spectra probably shows weak molecular interactions between plasmid DNA and vesicles containing DDAB, which is in accordance with the DNase I protection assay results.

\section{UCAI expression knockdown by shRNA}

To evaluate the efficacy of gene silencing with designed shRNA vector, UCA1 gene expression analysis was performed in MCF-7 cells. The expression inhibition rates are shown in Figure 4. Following 72 hours of transfection, UCA1 gene expression level revealed a significant reduction in all treated cells with different nanoformulations compared to the nontreated controls.

From a biological viewpoint, some recent reports demonstrate the negative correlation between UCA1 expression with caspase 3, tumor-suppressive miR-143, and metastasis in the breast cancer cell line. ${ }^{30,31}$ Han et al showed that increased expression of UCA1 leads to cell proliferation and antiapoptotic effect in colorectal cancer cell line and downregulation of UCA 1 causes cancer cell arrest. ${ }^{32}$ A more recent survey in breast cancer showed that the expression of UCA1 increases and promotes cell proliferation in vitro and in vivo. ${ }^{19}$

\section{Transfection efficiency}

Transfection efficiency of 6,512 bp UCA 1 shRNA plasmid was evaluated in a wide range of $(0.5-10 \mathrm{mM})$ of three ingredients: surfactant (Tween 80; T), squalene (S), and cationic lipid (didodecyldimethylammonium bromide [DDAB]) at the molar ratio of $1(\mathrm{~S}): 1(\mathrm{~T}):(0.08,0.12,0.16)$ (DDAB). Surfactant concentrations $>2.5 \mathrm{mM}$ caused detachment of the adherent MCF-7 cells and were evaluated as toxic for further applications. Therefore, lower concentrations have been considered for the following experiments. Efficient transfection in different $\mathrm{S}: \mathrm{T}: \mathrm{DDAB}$ complexes was 

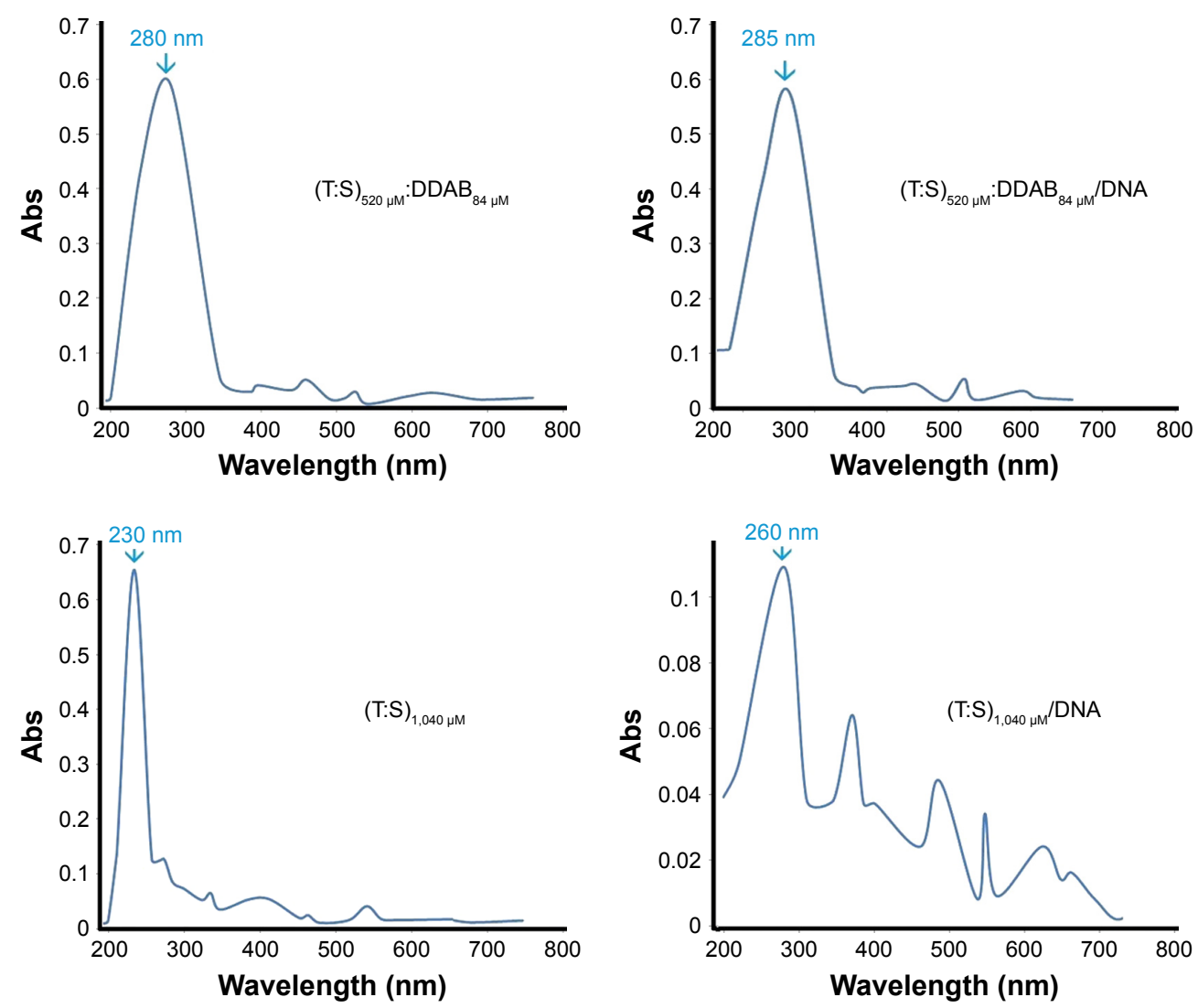

Figure 3 UV-visible spectra of the vesicles and polyplexes.

Note: All cationic vesicles comprised Tween 80 , squalene, and polyethylenimine $(4.3 \mu \mathrm{g} / \mathrm{mL})$.

Abbreviations: DDAB, didodecyldimethylammonium bromide; S, squalene; T, Tween 80; UV, ultraviolet.

not observed by fluorescence microscopy evaluation. The results of fluorescent microscopy are in accordance with the previously mentioned DNA protection assay. They showed that plasmid transfection failed with different concentrations

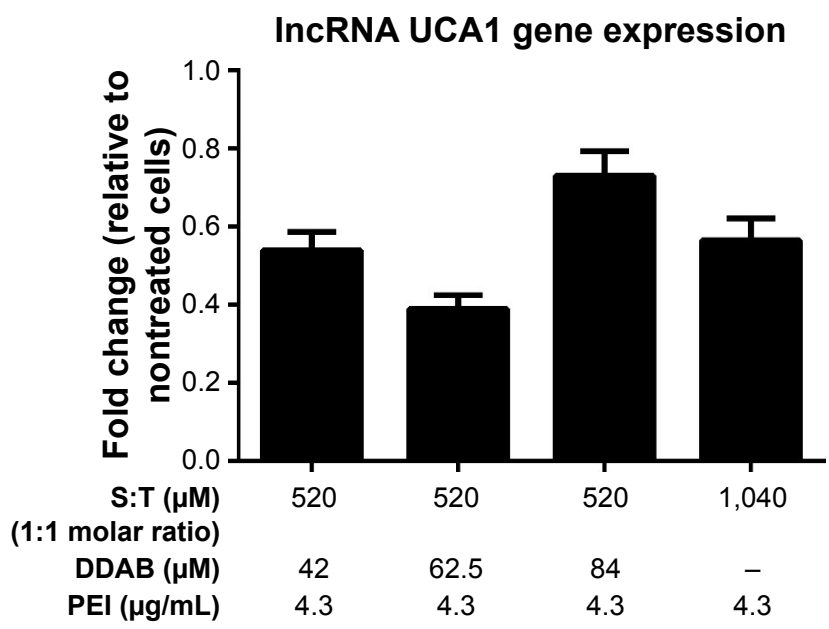

Figure 4 UCAI gene expression level in MCF-7 cell line.

Notes: Components of four vesicular formulations are represented below the chart. Student's $t$-test was used for analysis of significant differences $(P<0.05, n=3)$ and all treatments were significant compared with nontreated control (onefold). Abbreviations: DDAB, didodecyldimethylammonium bromide; PEI, polyethyleneimine; S, squalene; T, Tween 80 . of lipoplexes comprising Tween $80(520$ or $1,040 \mu \mathrm{M})$, squalene $(520$ or $1,040 \mu \mathrm{M})$, and cationic DDAB $(42,62.5$, or $84 \mu \mathrm{M})$.

Accordingly, PEI as a cationic polymer that improves plasmid DNA transfection efficiency was applied to the $\mathrm{T}: \mathrm{S}: \mathrm{DDAB}$ lipoplex. To understand the role of DDAB combined with PEI, three different concentrations of DDAB (42, 62.5, and $84 \mu \mathrm{M}$; DDAB) were selected for further experiments and evaluations. Moreover, for understanding the effect of the surfactant (T) and the excipient (S), two concentrations of $520 \mu \mathrm{M}: 520 \mu \mathrm{M}$ and 1,040 $\mu \mathrm{M}: 1,040 \mu \mathrm{M}$ of T:S with a constant amount of $1.3 \mu \mathrm{L}$ PEI $(1 \mathrm{mg} / \mathrm{mL})$ were selected for transfection of $5 \times 10^{5}$ MCF-7 cells in $300 \mu \mathrm{L}$ of medium $(4.3 \mu \mathrm{g} / \mathrm{mL})$. Fluorescent illumination (GFP channel) of the transfected cells with different vesicular formulations is shown compared with Lipofectamine ${ }^{\mathrm{TM}}$ 3000 as a positive control (Figure 5). For quantification of the transfection, Lipofectamine 3000 has been considered as a reference $(100 \%)$. The transfection ability and efficiency of $(\mathrm{T}: \mathrm{S})_{520 \mu \mathrm{M}}: \mathrm{D}_{42 \mu \mathrm{M}}:$ PEI, $(\mathrm{T}: \mathrm{S})_{520 \mu \mathrm{M}}: \mathrm{D}_{62.5 \mu \mathrm{M}}:$ PEI, (T:S) $520 \mu \mathrm{M}: \mathrm{D}_{84 \mu \mathrm{M}}:$ PEI, (T:S) $)_{1,040 \mu \mathrm{M}}: \mathrm{PEI},(\mathrm{T}: \mathrm{S})_{520 \mu \mathrm{M}}: \mathrm{PEI}$, and PEI, were $43 \%, 39 \%, 30 \%, 78 \%, 48 \%$, and $34 \%$, respectively. 
$(\mathrm{S}: \mathrm{T})_{520 \mu \mathrm{m}}: \mathrm{DDAB}_{42 \mu \mathrm{m}}: \mathrm{PEI}$

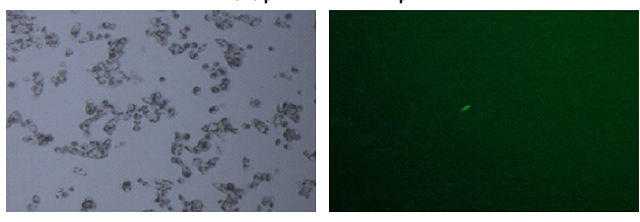

$(\mathrm{S}: \mathrm{T})_{520 \mu \mathrm{m}}: \mathrm{DDAB}_{84 \mu \mathrm{M}}:$ PEI

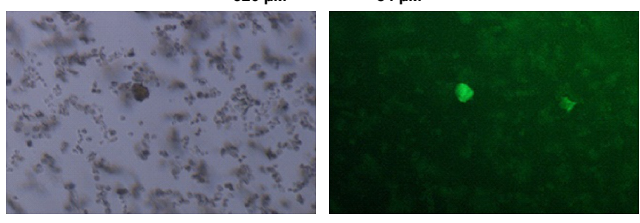

$(\mathrm{S}: \mathrm{T})_{1,040 \mu \mathrm{M}}:$ PEI

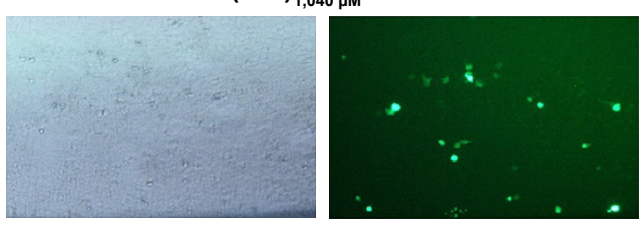

Lipofectamine
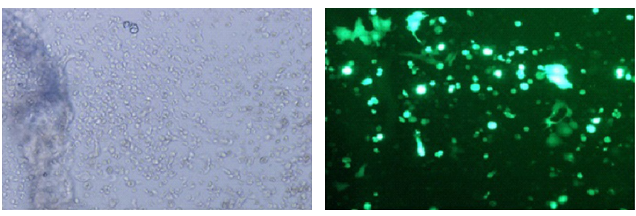

$(\mathrm{S}: \mathrm{T})_{520 \mathrm{\mu m}}$

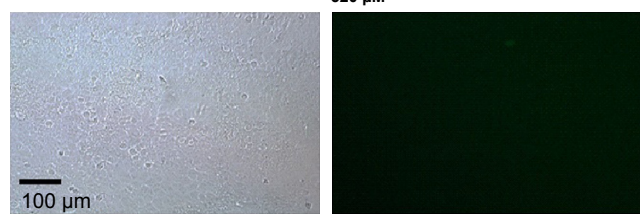

$(\mathrm{S}: \mathrm{T})_{520 \mu \mathrm{M}}: \mathrm{DDAB}_{62.5 \mu \mathrm{M}}: \mathrm{PEI}$

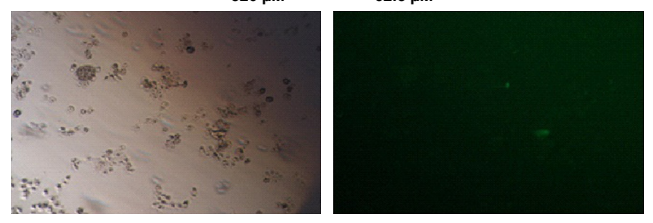

$(\mathrm{S}: \mathrm{T})_{520 \mu \mathrm{m}}: \mathrm{PEI}$

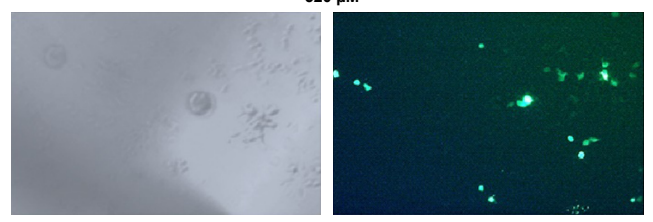

PEI

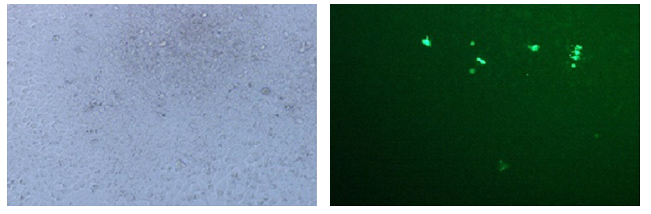

Figure 5 Transfection efficiency in MCF-7 cells with different cationic vesicles.

Notes: In all treatments, cells were transfected by polyplexes containing UCAI shRNA. Fluorescence microscopy images are shown in the right and images of the same cells obtained by light microscopy are shown in the left. In all PEl-containing treatments, the PEl concentrations were the same (I.3 $\mu \mathrm{L}$ PEl; I mg/mL) for transfection of $5 \times 10^{5}$ MCF-7 cells in $300 \mu \mathrm{L}$ of medium $(4.3 \mu \mathrm{g} / \mathrm{mL})$. Scale bar $=100 \mu \mathrm{m}$.

Abbreviations: DDAB, didodecyldimethylammonium bromide; PEI, polyethyleneimine; S, squalene; T, Tween 80.

Results showed that DDAB concentrations were not significantly related to the transfection efficiency, whereas applying two times the amount of vesicular components, $\mathrm{S}$ and $\mathrm{T}$, increased the transfection efficiency from $48 \%$ to $78 \%$.

DDAB has been used as a cationic lipid for liposomal plasmid transfection (usually smaller than $4 \mathrm{kD}$, based on our knowledge) and it potentially stabilizes liposomes by DNA complexation by charge neutralization. ${ }^{33}$ But in this work, it seems that DDAB cannot help in the transfection of large plasmid $(6.5 \mathrm{~kb})$. Here, low shRNA transfection efficiency of the vesicles containing DDAB can be interpreted with Zabner et al's ${ }^{29}$ explanation. They reported that the vesicles containing DDAB can form aggregations after endocytosis of cationic DNA lipoplexes. They showed that before the entry of DNA into the cell nucleus, lipid and DNA cannot dissociate properly and, in addition, they have weak endosomal scape, which is highly necessary for gene delivery, and even after the direct nuclear injection of a condensed lipid-DNA complex, they proved that DNA could not have proper transcription. Probably, DDAB as a cationic counterpart hindered successful transfection.

On the other hand, after endocytosis, PEI-DNA polyplexes have a great endosomal escape (proton sponge effect) because PEI leads to an influx of protons and water, and therefore, endosome swelling and disruption happens, which consequently releases the endosome content to the cytoplasm. ${ }^{34}$

Our data showed that PEI polyplex with $(\mathrm{T}: \mathrm{S})_{1,040 \mu \mathrm{M}}: \mathrm{PEI}$ formulation even had better transfection (78\%) relative to the intact PEI (34\%) for $6.5 \mathrm{kD}$ UCA1 shRNA plasmid, and UCA1 shRNA transfection efficiencies in different treatments were in this order: $(\mathrm{T}: \mathrm{S})_{1,040 \mu \mathrm{M}}: \mathrm{PEI}>(\mathrm{T}: \mathrm{S})_{520 \mu \mathrm{M}}: \mathrm{PEI}>$ PEI (intact PEI), when constant amount of $1.3 \mu \mathrm{g}(4.3 \mu \mathrm{g} / \mathrm{mL})$ of PEI was used in all formulations.

\section{Cancer cell toxicity}

MTS assay results for the MCF-7 cells and normal monocyte cells by different vesicular formulations after 72 hours of 

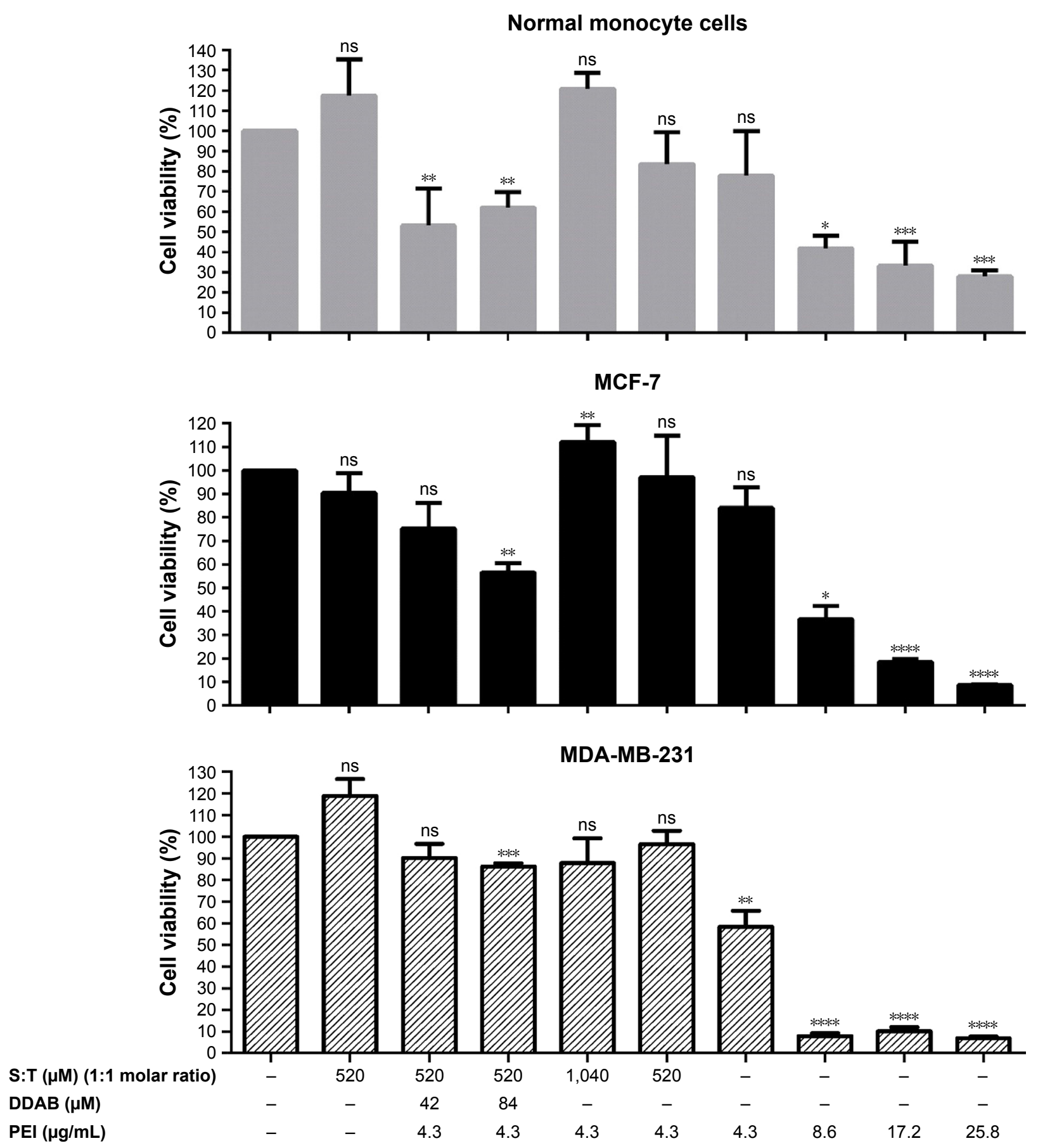

Figure 6 Cytotoxicity of cationic vesicles on MCF-7 and MDA-MB-23I cancer cell lines and normal monocyte cells.

Notes: Cells were treated with different concentrations of DDAB, surfactant, and PEI in vesicular formulations and evaluated at 72 hours after the UCAI shRNA treatment. The surviving cells were indirectly measured by MTS assay. The results are shown as the mean \pm SD of triplicates, as a percentage relative to the control. Student's $t$-test was used for analysis of significant differences $(P<0.05, n=3)$. S:T treatment (second column) and nontreated cells (first column) were used as two controls of our experiment. $* P<0.5, * * P<0.01, * * * P<0.001$, $* * * * P<0.0001$.

Abbreviations: DDAB, didodecyldimethylammonium bromide; MTS, 3-(4,5-dimethylthiazol-2-yl)-5-(3-carboxymethoxyphenyl)-2-(4-sulfophenyl)-2H tetrazolium, inner salt; ns, nonsignificant; PEI, polyethyleneimine; S, squalene; T, Tween 80.

UCA1 shRNA treatment are shown in Figure 6. No significant toxicity was observed for the vesicles composed of Tween 80 and squalene; it can be inferred that this composition promotes normal monocyte cell growth compared to nontreated cells. Furthermore, this formulation of Tween 80 and squalene (S:T) vesicle was considered as a control to find potential significant toxicity of other ingredients, PEI and DDAB. Promotional effect of (S:T) vesicles on normal monocyte cells can be attributed to squalene, as a natural lipid, as Puras et al reported similar result with squalene in the 
HEK-293 and ARPE-19 cells as application of niosomes containing squalene in the rat retina was safe and effective. ${ }^{35}$

Compared with PEI alone $\left(\mathrm{IC}_{50}\right.$ about $\left.7 \mu \mathrm{g} / \mathrm{mL}\right)$, no significant toxicity was observed in different vesicular formulations containing T, S, and a constant amount of PEI $(4.3 \mu \mathrm{g} / \mathrm{mL})$. Cell growth enhancement and reduction in toxicity were observed when the concentrations of Tween 80 and squalene were doubled $(1,040 \mu \mathrm{M}$ of $\mathrm{S}$ and $\mathrm{T}$, shown as $(\mathrm{T}: \mathrm{S})_{1,040 \mu \mathrm{M}}$ ) in both cell types.

The result showed that $\mathrm{DDAB}$ can be relatively toxic for the normal monocyte cells and MCF-7 cells, especially with higher concentration $(84 \mu \mathrm{M})$, which is not reported previously.

Among many cationic liposomes studied, a few formulations have the chance for clinical applications. The toxicity of some cationic lipids is an important problem in the application of vesicles. Many researchers have shown the toxicity of different cationic liposomes, ${ }^{36}$ but in most cases, the mechanisms of toxicity are not clear. It is possible that toxicity is caused by the interaction of the cationic lipids with cell organelle membranes ${ }^{36}$ and, additionally, it seems that the role of lipid molecular structure is more important than the zeta potential of the lipoplex. In this order, Filion and Phillips reported moderate toxicity of DDAB liposomes and showed that liposomes containing DDAB and other cationic lipids with similar positive zeta potentials have different toxicity in macrophage cells. ${ }^{37}$ Therefore, the details of the molecular mechanisms of DDAB on cell toxicity remain to be cleared.

DDAB potentially helps in the stability of vesicles by increasing the zeta potential. However, we observed that application of DDAB with PEI increased the relative cell toxicity, especially in higher concentrations (>42 $\mu \mathrm{M}$; Figure 6), and implementation and interpretation should be considered cautiously for further applications.

Compared to other drug delivery systems, there are some nanocarriers such as polyamidoamine dendrimers whose cytotoxicity is more severe than that of PEI at the same concentration. Although it makes their application in the gene delivery system difficult, ${ }^{38}$ surface-engineered dendrimers modified with lipids, peptides, polymers, nanoparticles, and other cationic moieties show promising potential for nucleic acid delivery. ${ }^{39}$

\section{Cell cycle measurement}

Cell cycle analysis was conducted to investigate the function of UCA1 following shRNA treatment in MCF-7 and MDA-MB-231 cancer cell lines and to find which nanoformulation is more effective. Flow cytometric analysis indicated that G2/M arrest was increased significantly in all UCA1 shRNA complexes formed by cationic vesicles from $20.9 \% \pm 0.25 \%$ for $(\mathrm{T}: \mathrm{S})_{520 \mu \mathrm{M}}$ vesicles (as control) to $32.8 \% \pm 0.55 \%, 34.2 \% \pm 0.33 \%, 45.5 \% \pm 11.5 \%$, $32.6 \% \pm 2.6 \%$, and $37.8 \pm 2.8$ in the $(\mathrm{T}: S)_{520 \mu \mathrm{M}}: \mathrm{D}_{42 \mu \mathrm{M}}: \mathrm{PEI}$, $(\mathrm{T}: \mathrm{S})_{520 \mu \mathrm{M}}: \mathrm{D}_{84 \mu \mathrm{M}}:$ PEI, (T:S) $)_{1,040 \mu \mathrm{M}}:$ PEI, (T:S) $)_{520 \mu \mathrm{M}}:$ PEI, and lipofectamine treatments, respectively (Figure 7). All treatments were composed of polyplex of UCA1 shRNA expression vector, except the control which contained a U6 plasmid or pRNAT-U6.1/Neo expression vector (without UCA1 shRNA).

Formulations with different amounts of DDAB caused significant cell cycle arrest, but compared with vesicles that only have PEI, it seems that DDAB and PEI do not have a synergistic effect. The vesicles containing only DDAB were not able to induce efficient transfection for a large $6.5 \mathrm{kD}$ plasmid used in this study (data not shown).

In addition, probably a twofold increase in Tween 80, as a surfactant, and squalene, as an excipient, with a constant amount of $1.3 \mu \mathrm{g}$ of PEI $(4.3 \mu \mathrm{g} / \mathrm{mL})$ improved the efficiency of vesicle formulation for $\mathrm{G} 2 / \mathrm{M}$ cell cycle arrest induction in $\mathrm{MCF}-7$ cells. This result is in accordance with more transfection efficiency of $(\mathrm{T}: \mathrm{S})_{1,040 \mu \mathrm{M}}:$ PEI relative to $(\mathrm{T}: \mathrm{S})_{520 \mu \mathrm{M}}:$ PEI based on fluorescence microscopy imaging and flow cytometry data; it can be interpreted that Tween 80 and squalene can help PEI in plasmid transfection in MCF-7 cells. Additionally, a slight decrease in cell toxicity of $\mathrm{MCF}-7$ cells and normal monocytes was observed for $(\mathrm{T}: \mathrm{S})_{1,040 \mu \mathrm{M}}:$ PEI relative to $(\mathrm{T}: \mathrm{S})_{520 \mu \mathrm{M}}:$ PEI. Also, our data are in accordance with $\mathrm{Li}$ et al's result which showed UCA1 overexpression reduced MCF-7 cell cycle arrest after tamoxifen treatment. ${ }^{40}$

\section{Apoptosis in MCF-7 cancer cells}

Significant apoptosis was observed following shRNA UCA1 treatment relative to $(\mathrm{T}: \mathrm{S})_{520 \mu \mathrm{M}}$ treatment as a control (Student's $t$-test analysis, $P>0.05$; Figure 8 ). The MCF-7 and MDA-MB-231 cancer cells were exposed (72 hours) to shRNA UCA1 complexed with different cationic vesicle formulations. In this study, total early and late apoptosis were used for the comparisons. Data showed that UCA1 shRNA polyplexes prepared by $(\mathrm{T}: \mathrm{S})_{520 \mu \mathrm{M}}: \mathrm{D}_{84 \mu \mathrm{M}}: \mathrm{PEI},(\mathrm{T}: \mathrm{S})_{1,040 \mu \mathrm{M}}$ : PEI, and $(\mathrm{T}: \mathrm{S})_{520 \mu \mathrm{M}}:$ PEI cationic vesicles induced significant apoptosis in MCF-7 cells $(P>0.05)$ relative to the void control U6 plasmid polyplex formed by $(\mathrm{T}: \mathrm{S})_{520 \mu \mathrm{M}}$ vesicles.

Huang et al showed G1 cell cycle arrest and increase in P27 protein with UCA1-siRNA in MCF-7 breast cancer cell line. They implied UCA1 RNA-heterologous nuclear ribonucleoprotein complex will competitively reduce the active 


\section{Cell cycle induced by UCA1 shRNA (72 hours) \\ MDA-MB-231}

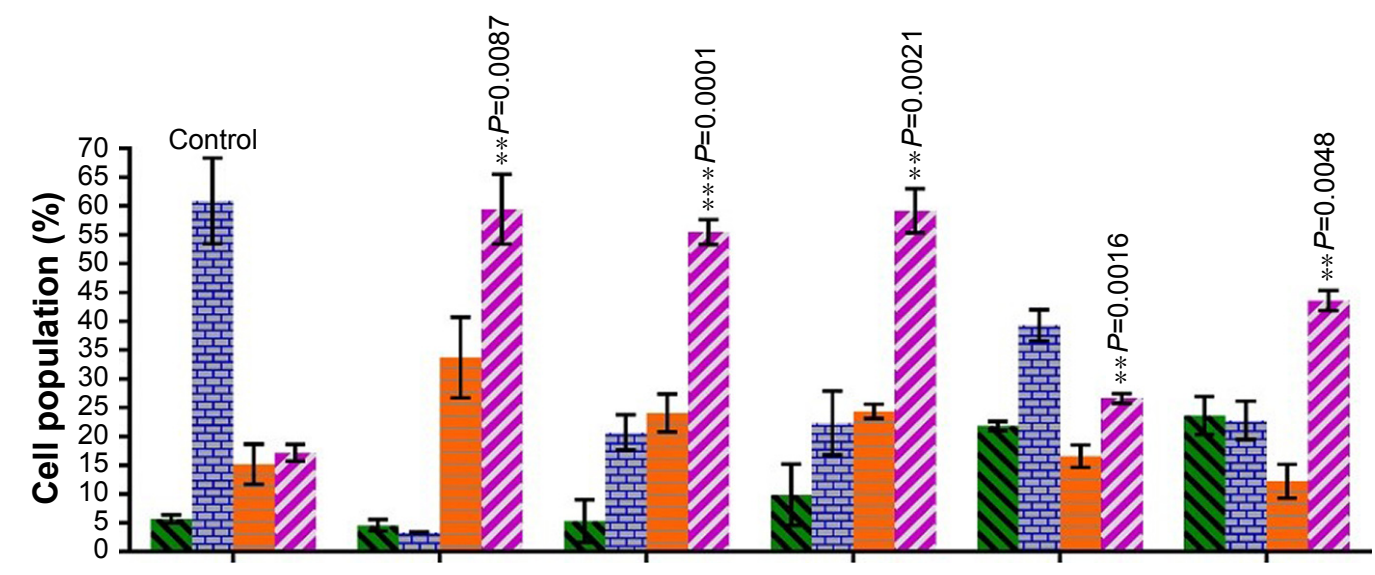

MCF-7

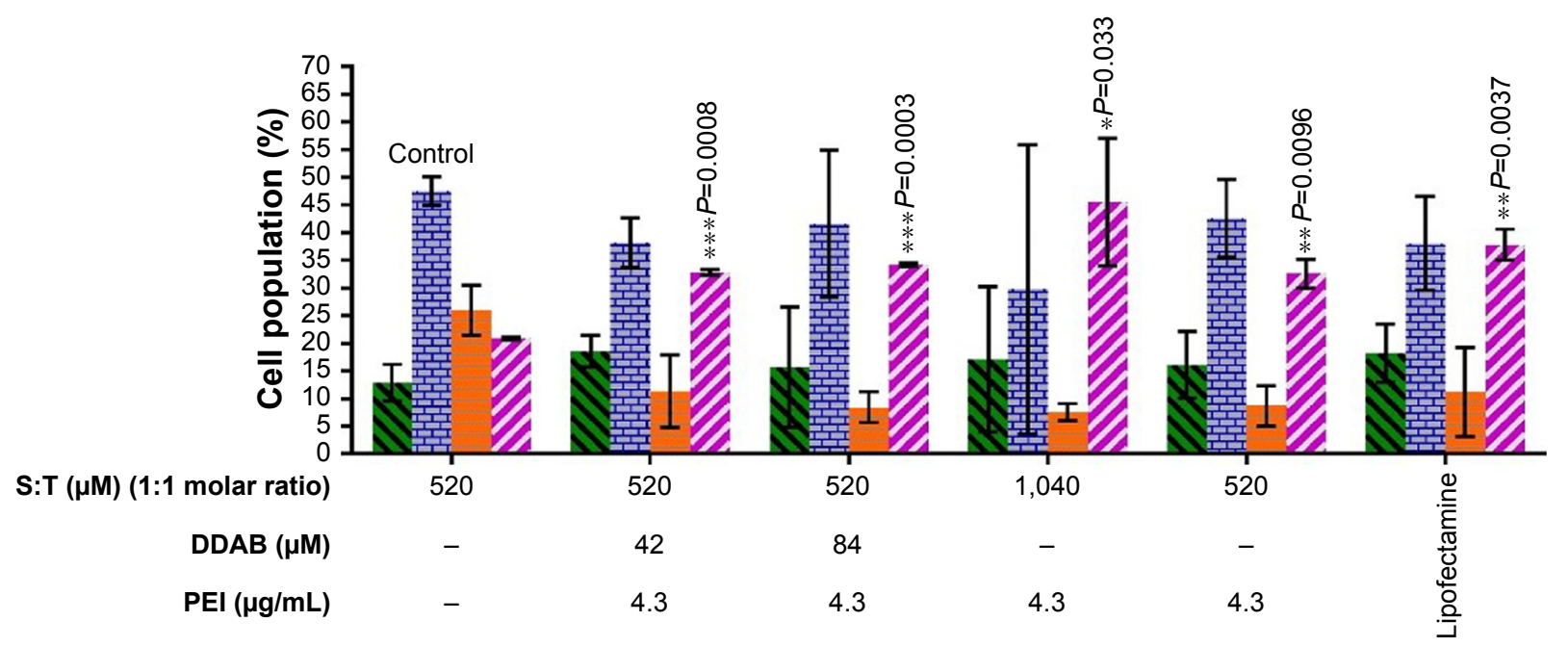

N Sub G1 $\quad$ G1 $\quad$ S

Figure 7 MDA-MB-23I and MCF-7 cell cycle arrest by different cationic vesicles containing UCAI shRNA vector.

Notes: All treatments contain shRNA UCAI transfecting vector, except for $(\mathrm{T}: \mathrm{S})_{520 \mathrm{\mu m}}$ control which contains a control U6 plasmid. The results are shown as mean \pm SD. Student's $t$-test was used for analysis of significant differences and the $P$-values for $G 2 / M$ arrest are shown for easier comparison. $* P<0.5$, $* * P<0.01$, $* * * P<0.00$ I.

Abbreviations: DDAB, didodecyldimethylammonium bromide; PEl, polyethyleneimine; S, squalene; T, Tween 80.

hnRNA, which subsequently decreases translocation of P27 mRNA from the nucleus to the cytoplasm of cells. ${ }^{41}$

From the nanostructural point of view, our data showed that formulations comprising a higher amount of DDAB $(84 \mu \mathrm{M})$ caused significant apoptosis. Similar to the cell cycle result, DDAB and PEI do not have a synergistic effect and the amount of $1.3 \mu \mathrm{g}$ of PEI $(4.3 \mu \mathrm{g} / \mathrm{mL})$ will be sufficient to transfect $6.5 \mathrm{kD}$ UCA1 shRNA plasmid into MCF-7 cancer cells.

Additionally, it seems that twofold increase of Tween 80 and squalene, with a constant amount of PEI, slightly increased the induction of apoptosis $\left(47.3 \pm 5.4\right.$ for $(\mathrm{T}: \mathrm{S})_{1,040 \mu \mathrm{M}}:$ PEI relative to $41.5 \pm 0.9$ for $(\mathrm{T}: \mathrm{S})_{520 \mu \mathrm{M}}:$ PEI vesicles; Figure 8$)$, while toxicity was reduced in MCF-7 cancer cells.

\section{Efficiency of nanoparticle gene delivery}

The efficiency of gene delivery into the tumor cells was investigated by examining the expression of GFP in tumor tissue 72 hours after injection of the complex of plasmid with $(\mathrm{T}: \mathrm{S})_{1,040 \mu \mathrm{M}}$ cationic vesicles. The mice were sacrificed and tumor tissue was harvested and subjected to immunohistochemical staining to track the fluorescence in the tissue sections. Fluorescence microscopy revealed fluorescing cells in the tumor tissue. It confirmed that cationic vesicles 
efficiently transferred the expression vector into the tumor cells (Figure 9).

\section{Conclusion}

We demonstrated that the downregulation of UCA1 leads to significant cell cycle arrest and apoptosis in MCF-7 cancer cells, which are in accordance with the previous findings of this noncoding RNA. ${ }^{41}$ Although the molecular mechanism of UCA1 in cell biology is not fully understood and needs further evaluations, it seems that downregulation of this IncRNA can be an appropriate approach for gene therapy against human breast cancer.

Among 100 different cationic lipids, only a few are appropriate for in vivo applications. Although many attempts were done to understand the physical and biological properties of cationic lipid-DNA for nucleic acid transfection, still mechanisms of the complexation remain to be cleared and need further evaluations. ${ }^{42}$ Nonionic surfactant Tween 80 has been commonly used in a range of pharmaceutical products. The combination of Tween 80 and squalene is somehow similar to the formulation of MF59 ${ }^{\circledR}$-adjuvanted influenza vaccine (by Novartis) which is tested in $>30$ countries and millions of people without significant safety and immunogenicity concerns. ${ }^{43}$

The cationic PEI-based vesicular nucleic acid nanoformulations provided effective transfection with a low level of cytotoxicity. Additionally, significant apoptotic effect of UCA1 shRNA was observed in MCF-7 cancer cells and it
A

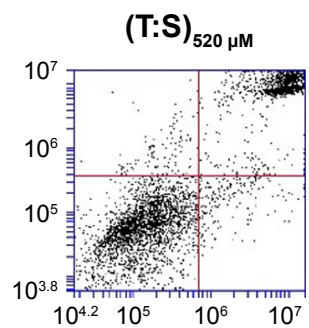

$(\mathrm{T}: \mathrm{S})_{1,040 \mu \mathrm{M}}: \mathrm{P}$

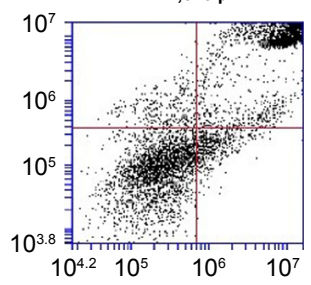

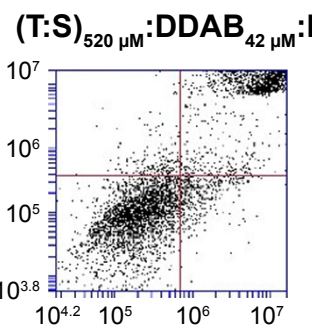

$(\mathrm{T}: \mathrm{S})_{520 \mu \mathrm{M}}: \mathrm{P}$

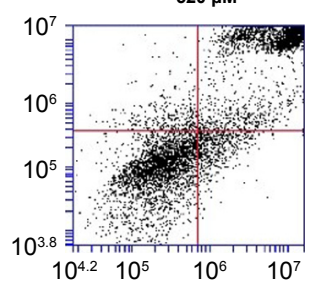

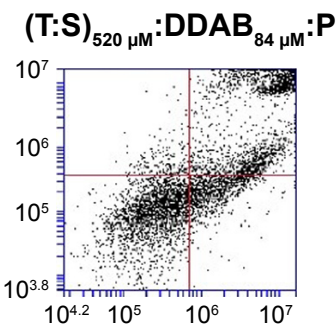

Lipofectamine

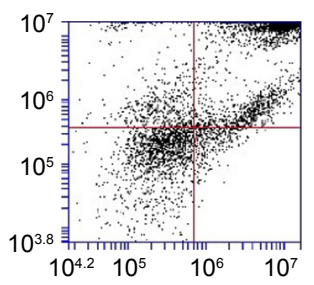

B

MCF-7 cell apoptosis induced by UCA1 shRNA (72 hours)

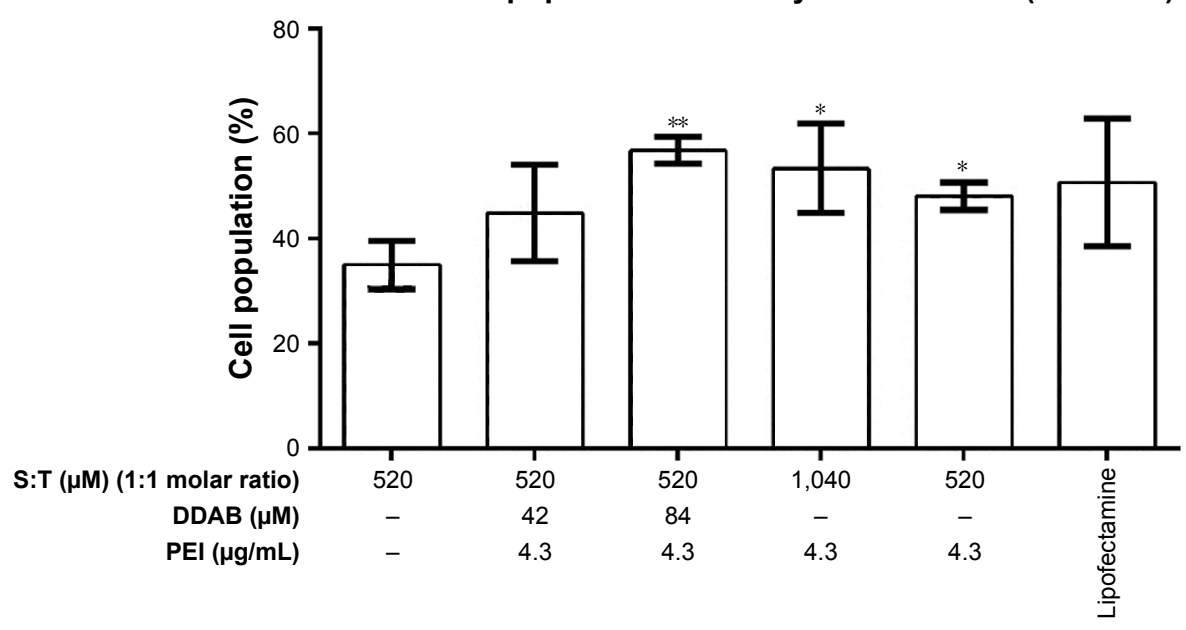

Figure 8 (Continued) 
C

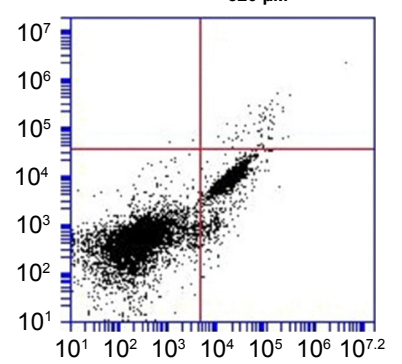

$(\mathrm{S}: \mathrm{T})_{1,040 \mu \mathrm{M}}:$ PEI

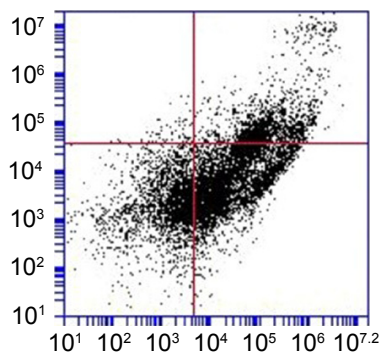

$(\mathrm{S}: \mathrm{T})_{520 \mu \mathrm{M}}:$ PEI

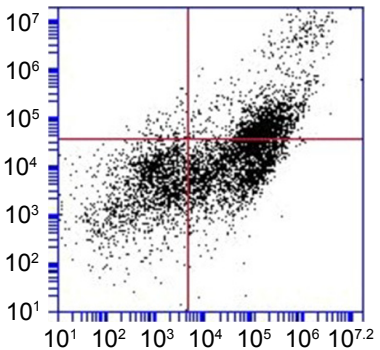

Lipofectamine

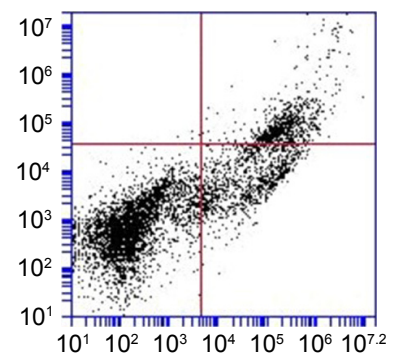

D

MDA-MB-231 cell apoptosis induced by UCA1 shRNA (72 hours)

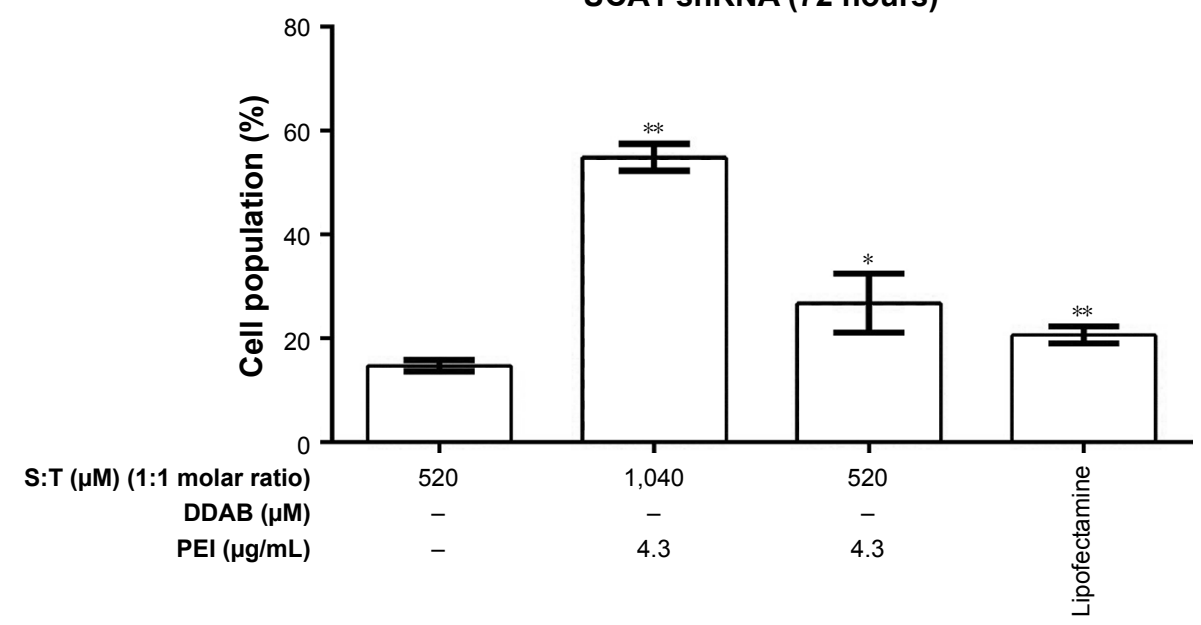

Figure 8 Apoptosis induction by shRNA UCAI complexed with different cationic vesicles in MCF-7 (A and B) and MDA-MB-23। (C and D) cancer cell lines.

Notes: (A and C) FITC Annexin V and PI staining assay results. (B and D) Early and late apoptosis were used together to show total apoptosis. The (T:S) 520 yM lipoplex was used as a control, which only had a U6 plasmid without shRNA UCAI transfecting vector. The results are shown as the mean \pm SD of three independent experiments. Student's $t$-test was used for the analysis of significant differences $(P<0.05, n=3)$. Significance is $* P<0.5$ and $* * P<0.01$.

Abbreviations: DDAB, didodecyldimethylammonium bromide; PEl, polyethyleneimine; PI, propidium iodide; $\mathrm{S}$, squalene; T, Tween 80.

showed that UCA1 RNAi can be potentially considered as an appropriate approach for breast cancer gene therapy.

The antiapoptotic effects of other regulatory noncoding genes remain to be investigated. Furthermore, other novel cationic polymers such as recombinant cationic polypeptides can be safer and more efficient alternative for cationic counterparts in future gene therapy surveys.

Here, we showed that $(\mathrm{T}: \mathrm{S})_{1,040 \mu \mathrm{M}}$ combination can compensate the toxicity of PEI (in a sufficient concentration for large plasmid transfection) to $\mathrm{MCF}-7$ and
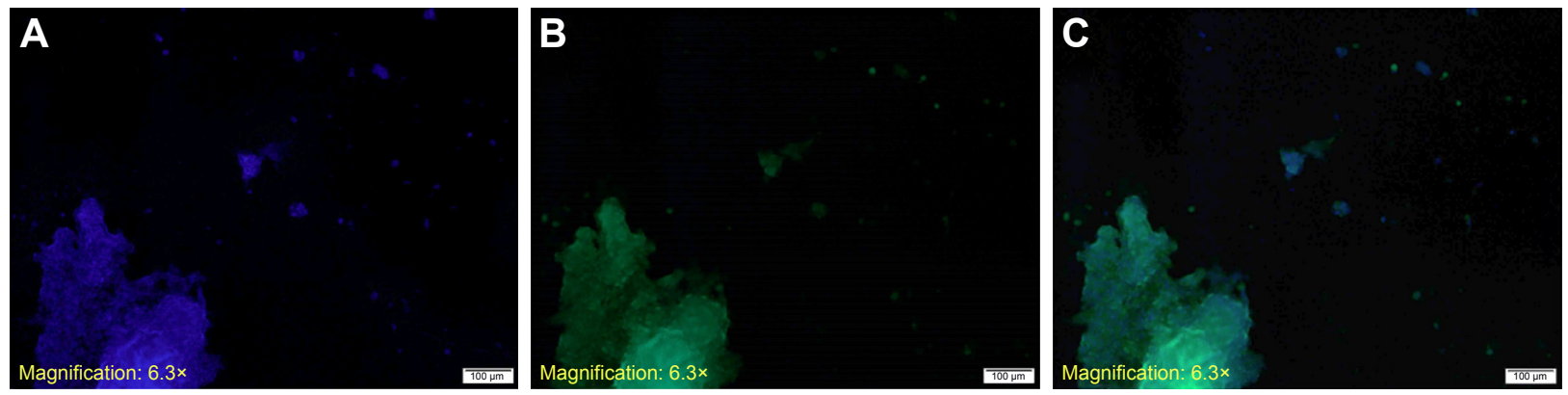

Figure 9 Immunohistochemical staining of breast tumor from mice.

Notes: Complex of plasmid with (T:S) $)_{1,040 \mu \mathrm{M}}$ cationic vesicles were injected in to the tumor. (A) Nuclei. (B) Cells expressing GFP. (C) Merged.

Abbreviations: $\mathrm{S}$, squalene; T, Tween 80 . 
MDA-MB-231 cancer cells. In summary, the vesicular nanocarrier, $(\mathrm{T}: \mathrm{S})_{1,040 \mu \mathrm{m}}$ with PEI, might be a useful tool for safe and efficient RNAi-based cancer gene therapy.

\section{Acknowledgments}

This project has been registered at Golestan University of Medical Sciences (Gorgan, Iran) and funded by the Deputy of Research and Technology of the university. The approval number from the constituted review board, the Ethics Committee of Golestan University of Medical Sciences (GOUMS) is IR-.GOUMS.REC.1395.134. We appreciate the voluntary blood donors, Mr Omid Barzegari and Mr Mohamad Arefi, for providing blood samples needed for normal monocyte experiments.

\section{Author contributions}

VEM designed the study and conceived the experiments with the help of BJ and analyzed the results and prepared the manuscript with the help of PM. PM conducted the experiments. MS and AS helped in spectrophotometer experiments and their analysis. All authors contributed toward data analysis, drafting and critically revising the paper, gave final approval of the version to be published, and agree to be accountable for all aspects of the work.

\section{Disclosure}

Mahrokh Sharbatkhari is employed by Arya Tina Gene Biopharmaceutical Company (Gorgan, Iran); the authors report no other conflicts of interest in this work.

\section{References}

1. Kazi KM, Mandal AS, Biswas N, et al. Niosome: a future of targeted drug delivery systems. J Adv Pharm Technol Res. 2010;1(4):374.

2. Manosroi J, Khositsuntiwong N, Götz F, Werner RG, Manosroi W, Manosroi A. Potent melanin production enhancement of human tyrosinase gene by Tat and an entrapment in elastic cationic niosomes: potential application in vitiligo gene therapy. Chem Biol Drug Des. 2012; 80(6):953-960.

3. Rajera R, Nagpal K, Singh SK, Mishra DN. Niosomes: a controlled and novel drug delivery system. Biol Pharm Bull. 2011;34(7):945-953.

4. Hao Y, Zhao F, Li N, Yang Y, Li K. Studies on a high encapsulation of colchicine by a niosome system. Int J Pharm. 2002;244(1-2):73-80.

5. Azmin MN, Florence AT, Handjani-Vila RM, Stuart JF, Vanlerberghe G, Whittaker JS. The effect of non-ionic surfactant vesicle (niosome) entrapment on the absorption and distribution of methotrexate in mice. J Pharm Pharmacol. 1985;37(4):237-242.

6. Mahale NB, Thakkar PD, Mali RG, Walunj DR, Chaudhari SR. Niosomes: novel sustained release nonionic stable vesicular systems - an overview. Adv Colloid Interface Sci. 2012;183-184:46-54.

7. Puras G, Mashal M, Zárate J, et al. A novel cationic niosome formulation for gene delivery to the retina. J Control Release. 2014;174:27-36.

8. Yin JQ, Gao J, Shao R, Tian WN, Wang J, Wan Y. siRNA agents inhibit oncogene expression and attenuate human tumor cell growth. J Exp Ther Oncol. 2003;3(4):194-204.
9. Pai SI, Lin YY, Macaes B, Meneshian A, Hung CF, Wu TC. Prospects of RNA interference therapy for cancer. Gene Ther. 2006;13(6): 464- 477.

10. Rossi JJ. RNAi as a treatment for HIV-1 infection. Biotechniques. 2006;40(4S):S25-S29.

11. Devi GR. siRNA-based approaches in cancer therapy. Cancer Gene Ther. 2006;13(9):819-829.

12. Taxman DJ, Moore CB, Guthrie EH, Huang MT. Short hairpin RNA (shRNA): design, delivery, and assessment of gene knockdown. In: Sioud M (editor). RNA Therapeutics. Methods in Molecular Biology (Methods and Protocols); volume 629. New York, NY: Humana Press. 2010:139-156.

13. Wu MT, Wu RH, Hung CF, Cheng TL, Tsai WH, Chang WT. Simple and efficient DNA vector-based RNAi systems in mammalian cells. Biochem Biophys Res Commun. 2005;330(1):53-59.

14. Yang L, Cao Z, Li F, et al. Tumor-specific gene expression using the survivin promoter is further increased by hypoxia. Gene Ther. 2004; 11(15):1215-1223.

15. Wang XS, Zhang Z, Wang HC, et al. Rapid identification of UCA1 as a very sensitive and specific unique marker for human bladder carcinoma. Clin Cancer Res. 2006;12(16):4851-4858.

16. Hajjari M, Khoshnevisan A, Shin YK. Molecular function and regulation of long non-coding RNAs: paradigms with potential roles in cancer. Tumour Biol. 2014;35(11):10645-10663.

17. Wang F, Li X, Xie X, Zhao L, Chen W. UCA1, a non-protein-coding RNA up-regulated in bladder carcinoma and embryo, influencing cell growth and promoting invasion. FEBS Lett. 2008;582(13):1919-1927.

18. Shi X, Sun M, Liu H, Yao Y, Song Y. Long non-coding RNAs: a new frontier in the study of human diseases. Cancer Lett. 2013;339(2): 159-166.

19. Bian Z, Jin L, Zhang J, et al. LncRNA-UCA1 enhances cell proliferation and 5-fluorouracil resistance in colorectal cancer by inhibiting miR-204-5p. Sci Rep. 2016;6:23892.

20. Wheeler CJ, Felgner PL, Tsai YJ, et al. A novel cationic lipid greatly enhances plasmid DNA delivery and expression in mouse lung. Proc Natl Acad Sci U S A. 1996;93(21):11454-11459.

21. Rajput S, Puvvada N, Kumar BN, et al. Overcoming Akt induced therapeutic resistance in breast cancer through siRNA and thymoquinone encapsulated multilamellar gold niosomes. Mol Pharm. 2015;12(12): 4214-4225.

22. Opanasopit P, Leksantikul L, Niyomtham N, et al. Cationic niosomes an effective gene carrier composed of novel spermine-derivative cationic lipids: effect of central core structures. Pharm Dev Technol. 2015; 2016;7450.

23. Tagalakis AD, Maeshima R, Yu-Wai-Man C, et al. Peptide and nucleic acid-directed self-assembly of cationic nanovehicles through giant unilamellar vesicle modification: targetable nanocomplexes for in vivo nucleic acid delivery. Acta Biomater. 2017;51:351-362.

24. Midoux P, Breuzard G, Gomez JP, Pichon C. Polymer-based gene delivery: a current review on the uptake and intracellular trafficking of polyplexes. Curr Gene Ther. 2008;8(5):335-352.

25. Varga C, Tedford NC, Thomas M, Klibanov AM, Griffith LG, Lauffenburger DA. Quantitative comparison of polyethylenimine formulations and adenoviral vectors in terms of intracellular gene delivery processes. Gene Ther. 2005;12(13):1023-1032.

26. Erfani-Moghadam V, Nomani A, Zamani M, Yazdani Y, Najafi F, Sadeghizadeh M. A novel diblock of copolymer of (monomethoxy poly [ethylene glycol]-oleate) with a small hydrophobic fraction to make stable micelles/polymersomes for curcumin delivery to cancer cells. Int J Nanomedicine. 2014;9:5541.

27. Discher DE, Eisenberg A. Polymer vesicles. Science. 2002;297(5583): 967-973.

28. Perales JC, Ferkol T, Beegen H, Ratnoff OD, Hanson RW. Gene transfer in vivo: sustained expression and regulation of genes introduced into the liver by receptor-targeted uptake. Proc Natl Acad Sci US A. 1994;91(9):4086-4090. 
29. Zabner J, Fasbender AJ, Moninger T, Poellinger KA, Welsh MJ. Cellular and molecular barriers to gene transfer by a cationic lipid. J Biol Chem. 1995;270(32):18997-19007.

30. Tuo YL, Li XM, Luo J. Long noncoding RNA UCA1 modulates breast cancer cell growth and apoptosis through decreasing tumor suppressive miR-143. Eur Rev Med Pharmacol Sci. 2015;19(18):3403-3411.

31. Hiemer SE, Szymaniak AD, Varelas X. The transcriptional regulators TAZ and YAP direct transforming growth factor $\beta$-induced tumorigenic phenotypes in breast cancer cells. J Biol Chem. 2014;289(19): 13461-13474.

32. Han Y, Yang YN, Yuan HH, et al. UCA1, a long non-coding RNA upregulated in colorectal cancer influences cell proliferation, apoptosis and cell cycle distribution. Pathology. 2014;46(5):396-401.

33. Marty R, N'Soukpoé-Kossi CN, Charbonneau D, Weinert CM, Kreplak L, Tajmir-Riahi HA. Structural analysis of DNA complexation with cationic lipids. Nucleic Acids Res. 2009;37(3):849-857.

34. Boussif O, Lezoualc'h F, Zanta MA, et al. A versatile vector for gene and oligonucleotide transfer into cells in culture and in vivo: polyethylenimine. Proc Natl Acad Sci U S A. 1995;92(16):7297-7301.

35. Puras G, Mashal M, Zárate J, et al. A novel cationic niosome formulation for gene delivery to the retina. J Control Release. 2014;174:27-36.

36. Marianecci C, Di Marzio L, Rinaldi F, et al. Niosomes from 80 s to present: the state of the art. Adv Colloid Interface Sci. 2014;205:187-206.
37. Filion MC, Phillips NC. Toxicity and immunomodulatory activity of liposomal vectors formulated with cationic lipids toward immune effector cells. Biochim Biophys Acta. 19973;1329(2):345-356.

38. Mendes LP, Pan J, Torchilin VP. Dendrimers as nanocarriers for nucleic acid and drug delivery in cancer therapy. Molecules. 2017;22(9). pii:E1401.

39. Yang J, Zhang Q, Chang H, Cheng Y. Surface-engineered dendrimers in gene delivery. Chem Rev. 2015;115(11):5274-5300.

40. Li X, Wu Y, Liu A, Tang X. Long non-coding RNA UCA1 enhances tamoxifen resistance in breast cancer cells through a miR-18a-HIF1 $\alpha$ feedback regulatory loop. Tumour Biol. 2016;37(11):14733-14743.

41. Huang J, Zhou N, Watabe K, et al. Long non-coding RNA UCA1 promotes breast tumor growth by suppression of p27 (Kip1). Cell Death Dis. 2014;5(1):e1008.

42. Ewert K, Slack NL, Ahmad A, et al. Cationic lipid-DNA complexes for gene therapy: understanding the relationship between complex structure and gene delivery pathways at the molecular level. Curr Med Chem. 2004;11(2):133-149.

43. O'Hagan DT, Ott GS, Nest GV, Rappuoli R, Giudice GD. The history of MF59(®) adjuvant: a phoenix that arose from the ashes. Expert Rev Vaccines. 2013;12(1):13-30.
International Journal of Nanomedicine

\section{Publish your work in this journal}

The International Journal of Nanomedicine is an international, peerreviewed journal focusing on the application of nanotechnology in diagnostics, therapeutics, and drug delivery systems throughout the biomedical field. This journal is indexed on PubMed Central, MedLine, CAS, SciSearch $®$, Current Contents $\AA /$ Clinical Medicine,

\section{Dovepress}

Journal Citation Reports/Science Edition, EMBase, Scopus and the Elsevier Bibliographic databases. The manuscript management system is completely online and includes a very quick and fair peer-review system, which is all easy to use. Visit http://www.dovepress.com/ testimonials.php to read real quotes from published authors. 